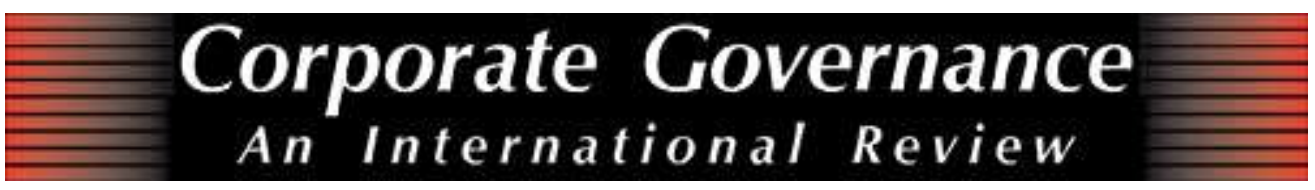

\title{
NEW INVESTMENT FUNDS, RESTRUCTURING, AND LABOR OUTCOMES: A EUROPEAN PERSPECTIVE
}

\begin{tabular}{|r|l|}
\hline Journal: & Corporate Governance: An International Review \\
\hline Manuscript ID: & CGIR-2010-0084PE.R3 \\
\hline Manuscript Type: & Private Equity Issue \\
\hline Keywords: & $\begin{array}{l}\text { Corporate Social Performance }<\text { Firm-Level Governance Outcomes, } \\
\text { Ownership Mechanisms, European Economy(s) < Governance } \\
\text { Environments }\end{array}$ \\
\hline \multicolumn{2}{|l}{} \\
\hline
\end{tabular}

\section{SCHOLARONE \\ Manuscripts}




\title{
NEW INVESTMENT FUNDS, RESTRUCTURING, AND LABOR OUTCOMES: A EUROPEAN PERSPECTIVE
}

\begin{abstract}
Manuscript Type: Empirical

Research Question: This article considers the consequences for employment, work organisation, and industrial relations where companies are acquired by private equity, hedge funds, or sovereign wealth funds. It also assesses the role of national labour regulation in moderating labor outcomes
\end{abstract}

Research Findings: The article draws on three case studies - a Spanish supermarket chain, a German engineering company, and a ports and logistics group hitherto based in the UK. Employment reductions are found in each case, though to varying extents. There are few changes in work organization but some developments in employee voice and representation. National systems of labour regulation do not impact substantially on employment reductions but they do affect the extent to which worker representatives receive information after (though not during) the acquisition.

Theoretical Implications: Contrary to extant theory, the extent of national employment regulation does not appear to be an impediment to restructuring by investment funds. The differential effect of the three funds suggests that the extent of ownership is not decisive in explaining the level of activism or its impacts on labor. Instead, the objectives and time frames of funds appear to be more important.

Policy Implications: The implication of the findings is that greater disclosure and regulation of new investment funds is more likely to enhance employee protection than further labor regulation. Broadly, this has been the main thrust of recent policy within European Union institutions. 


\section{INTRODUCTION}

The activities of investment funds, such as private equity (PE), hedge funds (HF), and sovereign wealth funds (SWF), have been controversial in Europe and beyond, especially in relation to their effects on labor and employment. On the one hand, European trade unions and the European Socialist Party group of parliamentarians have been major critics. In a study of PE and HFs, the Socialist Party argued that funds threaten the viability of target companies, lead to employment reductions and wage cuts, put pensions at risk, and ignore employee voice (European Socialist Party, 2008). On the other hand, the European Venture Capital Association, representing PE funds, argues that $\mathrm{PE}$ is engaged in value creation rather than value destruction or value redistribution. PE funds inject new investment and new management and, in the long-term, have a beneficial effect on employment and jobs in the companies which they acquire. According to this view, the cases where PE has had adverse effects on employees are relatively few, but have attracted a disproportionate amount of publicity. Moreover, these instances tend to be where target firms have been weak performers with poor prospects (European Venture Capital Association, 2008). For their part, HFs make similar defences of their activities, arguing that activist involvement in firms is relatively rare, HFs bring liquidity to markets, and their higher returns lead to real benefit to workers, not least for the pension funds which invest in them (see for example the Alternative Investment Management Association material quoted in Gospel, Haves, Pendleton, Vitols, and Wilke, 2010: 88).

This debate between protagonists has been mirrored by controversy among academics, at least in relation to PE. Some large-scale US survey evidence has suggested that PE tends to be associated with job growth, at least in the medium term (World Economic Forum, 2010). Similarly, surveys have found that on the whole there have been few changes in industrial relations institutions and procedures in PE buy-outs (Bacon et al., 2010). Against this, there is evidence from more detailed cases of large-scale job loss, intensification of working practices, and a reduction in employee voice, including withdrawal of union recognition (Clark, 2009b). Methodological considerations have a 
substantial bearing on findings, with the more positive accounts of PE effects vulnerable to charges of respondent and survivor biases, whilst the more negative cases studies are questionable on grounds of their typicality and representativeness (Lutz and Achleitner, 2010). More nuanced accounts suggest that PE funds are neither 'angels nor demons' (Lutz and Achleitner, 2010) and that there are variations in labor effects between sub-species of buy-outs (Wood and Wright, 2010). Meanwhile, to our knowledge, there are no academic studies of the labor effects of HFs and SWFs.

This article contributes to these debates by examining the labor and employment effects in three companies acquired or invested in by these three types of investment funds. Two main research questions are addressed. First, to what extent, and in what ways, is labor affected by the intervention of investment funds? Specifically, do fund interventions lead to employment change, modifications to work organization and working practices, and reductions or enhancement of employee voice and representation? How far does the extent of labor and employment change correspond to the extent of ownership by these funds? Second, does national labor regulation have a significant moderating effect on labor outcomes arising from fund interventions? There are two aspects to this: does the extent of employment protection regulation affect the amount of employment change and how far do national systems of employee voice enable employees and their representatives to influence restructuring processes?

The article draws on three case studies of firms which have been the subject of interventions by investment funds. The first is a Spanish company acquired by a British PE fund; the second concerns a German company subject to intervention by a US HF; and the third involves a British company acquired by a Dubai SWF. These company cases were developed from material researched for the European Commission by the present authors and later extended by them. The cases were selected to provide a spread of investment fund types, with varying degrees of ownership. In so far as this is possible with a small number of cases, they were selected to be representative of typical fund acquisitions rather than extreme or polar types. In each case the target company was a large firm 
operating in a mature industry, and which was to some extent under-performing or under-valued, but not in imminent danger of collapse. On the one hand, significant organic growth was unlikely given the maturity of the sectors, and value gains could mainly be realized through restructuring. On the other hand, these were not turnaround situations where radical changes were necessary to ensure survival. To permit evaluation of the second set of research questions, a further factor in case selection was the need to include national industrial relations contexts with varying degrees of labor regulation. We selected cases from a relatively unregulated labor context (the UK), from one where worker protection and representation has a well-developed legal form (Germany), and from one (Spain) where the employment relations system is said to take a hybrid or Latin form (Aguilera, 2005).

The findings from the cases suggest that the involvement of these funds does not automatically lead to either large job losses / job additions or deterioration / improvements in terms and conditions of employment at target companies. Whilst overall headcount employment was reduced in the three cases, this was mainly achieved by transfers to other employers rather than layoffs, though, as will be discussed below, this is a significant consideration for employees. It is notable that the largest reduction in employment was found in the case involving the HF, and in the national context where labour protection is most extensive. In terms of work organization, there were no dramatic changes in the organization of labor, the intensity of work, and how jobs are performed in any of the cases. As for industrial relations, it is striking that there was little involvement of employee representatives in information disclosure and consultation concerning the acquisition of shares or takeover of the company, despite well-developed employee voice systems in at least one of our cases. However, the presence of a new owner did not subsequently led to substantial reductions in employee voice and representation. Indeed in one case, employee voice institutions have been enhanced. 
The cases generate interesting implications for extant governance and labor theory. First, the extent of ownership by these investment funds is less important in influencing labor outcomes than the objectives and time horizons of the fund. This is illustrated especially by the HF case where a relatively small ownership stake was nevertheless associated with substantial changes in some aspects of employment. These changes emanated from a concern by the HF to transfer value to shareholders in a relatively short period of time. Second, national systems of labor regulation do not appear to have a significant moderating effect on the extent of employment reductions and changes. The largest fall in employment amongst our cases is found in a company operating in the most regulated national system. Nor does the extent of national regulation on worker voice affect the amount of information and voice which is given to workers before and during the acquisition process.

However, confirming earlier research, it does affect the extent to which worker representatives receive information after the acquisition (Bruining, Boselie, Wright, and Bacon, 2005; Bacon, Wright, Scholes, and Meuleman, 2010).

This last point notwithstanding, our results have two major implications for policy and practice. First, the extent of employment protection and representation regulation does not appear to be a major impediment to restructuring by these various investment funds. Second, for those concerned about the employment consequences of fund interventions, greater regulation of the funds themselves (e.g. greater requirements to disclose information) might be more effective than further regulation on employment protection (Bacon et al., 2010).

The paper is organized as follows. In the following section, the nature, extent, and activities of the three types of investment funds are considered. The next section then deals with purported links between funds and labor outcomes and provides a brief survey of the existing empirical literature. These sections place the cases in context. The following section outlines the research methods and presents evidence from the cases. The final section discusses the implications of these findings for theory, further research, and policy discussions. 


\section{BACKGROUND: THE NATURE AND EXTENT OF INVESTMENT FUNDS}

\section{Private Equity}

PE funds invite subscriptions from institutional investors and wealthy individuals to make investments in their funds. These investors become partners and have their capital tied up for a period of time - usually the lifetime of the fund which typically runs for 10-12 years. The fund managers (general partners) charge these investors (limited partners) an annual management fee (typically 2 per cent) and take a part (20 per cent) of the annual returns of the fund above a preagreed hurdle rate payable to investors (so-called carried interest) (Gilligan and Wright, 2010).

This pooling of capital is used to acquire existing companies or subsidiaries, generally with a view to restructuring and developing their operations prior to a resale or stock-market flotation at some time in the future. The most dramatic cases have been public-to-private transactions, whereby large listed companies are taken into private ownership (e.g. in Europe, Alliance Boots in the UK or Gambro in Sweden). Typically, most of the purchase price is financed by debt, much of which is secured against the assets or income stream of the acquired company. The remainder is contributed by the PE fund. Funds, either singly or in conjunction with other funds, acquire target companies, usually in their entirety. Unlike most institutional investors in equity markets (pension, insurance, and mutual funds), PE fund managers take an activist approach to their investee companies. The top managers of these targets, sometimes newly installed by the PE house, are monitored closely and their incentives tied to the achievement of restructuring goals (Gilligan and Wright, 2010). In this way the aim is to reduce the agency costs of ownership. Nevertheless, there is some debate about the nature of the PE business model. Some view it as primarily based on financial engineering whereby returns are mainly secured via leverage (Folkman, Froud, Williams, and Johal, 2009), whilst others see it as involving restructuring of under-performing firms to enhance performance (World Economic 
Forum, 2008). Both conceptions, but in particular the latter, have potentially important implications for labor and employment.

A notable feature of PE funds is that they are relatively less regulated and typically have fewer obligations to disclose than other types of institutional investors. As private companies, PE-owned businesses are also generally exempt from the corporate governance requirements faced by stock market-listed firms. This lack of disclosure can present problems for employees and their representatives in responding to managerial restructuring initiatives. It is also important to note that when PE takeovers are achieved through share transactions, they are not viewed as a change of control that would trigger employee rights to information and employment protection under present European Union legislation.

\section{Hedge funds}

HFs are usually identified by four characteristics: they are pooled, privately organized investment vehicles; they are not usually available to retail investors; they are administered by professional investment managers with performance-based pay and significant investments in the fund; and they operate largely outside of national securities regulation and registration requirements (Brav, Jiang, Partnoy, and Thomas, 2008: 1735). As such, HFs are usually exempt from the requirement typically faced by pension funds and mutual funds to hold diversified portfolios. As investment funds, they tend to be lightly regulated and have fewer obligations to disclose their activities than other types of investment fund.

In terms of equity investments, a variety of strategies can be adopted by HFs, but the most important in the context of employment are directional and event driven strategies. In the former, HFs seek margins by exploiting, and possibly even causing, market movements. Short selling is a classic case of this. In the latter, they secure returns through interventions in socalled special situations such as mergers and takeovers. Activism, where a fund takes an 
ownership stake and aims to influence management strategies and decisions, is one form of event-driven strategy. Activist HFs are defined by the Organisation for Economic Cooperation and Development as 'investment vehicles that seek, often through the exercise of voting power or the threat of it, to influence publicly held companies to take actions that the HF believes will increase the company's value' (OECD 2007: 8). There are a relatively small number of activist HFs, accounting for about 5 per cent of total HF assets under investment and about a quarter of assets used for event-driven strategies (OECD, 2007: 22).

Like PE, HF activism is aimed at strategic re-direction of target companies. However, unlike PE, activist HFs rarely seek majority control, though they may build up sizeable stakes (Brav et al., 2008). The primary objective of most interventions by activist HFs is to pressurise managers to increase returns to shareholders. As such they usually rely on varying degrees of cooperation with the existing management and shareholders. However, the most visible cases tend to be those where HFs contest the actions of incumbent managers. US evidence suggests that HFs tend to focus more often on value transfers than changes to business and operating strategies (Klein and Zur, 2009). Interventions are usually aimed at initiating cash dividends and share buy-backs, cutting top management pay, and securing board seats. Again, US evidence indicates that activist HFs typically target under-valued, but nevertheless either wellperforming firms or those with good growth potential (Brav et al., 2008).

\section{Sovereign Wealth Funds}

SWFs are investment funds operated by governments or their agencies. They are used by countries with large foreign reserves to obtain a higher rate of return on their assets by investing in international markets than would be available from government bonds or other investments in the home country (Sethi, 2008: 12). The largest SWFs are based in the Gulf states and United Arab Emirates (e.g. Abu Dhabi, Qatar, Kuwait), Saudi Arabia, Singapore, Norway, and China. 
SWFs have given rise to widespread concern because they enable overseas governments to acquire important stakes in companies in other countries, thereby offering the potential to exert strategic, but largely hidden, influence on other countries' economies. Overwhelmingly, they tend to be secretive about their holdings and strategies, being concerned not to reveal much about positions and being aware of charges of interference. As a result, even less information tends to be disclosed by SWFs than by PE and HFs.

SWFs have traditionally taken a passive approach to their investments, allowing incumbent managements to remain in place and making few demands for changes in operations. They have typically also held minority stakes so as not to attract unwelcome attention in host countries. However, there is some evidence that SWFs are beginning to take a more activist role, especially where they acquire majority stakes (Sethi, 2008: 13-17). There are also a growing number of cases of where funds or their affiliates have acquired full control of companies. In addition, SWFs are becoming increasingly involved with PE and HFs as both limited and general partners (Bortolotti, Fotak, Megginson, and Miracky, 2009).

\section{LINKS WITH LABOR OUTCOMES: RHETORIC, THEORY, AND PRACTICE}

\section{Linkages}

The activities of investment funds may affect labor and employment in several ways. First, new investment fund owners may affect corporate strategies. The acquisition of a sizeable proportion of shares or the total quantity of shares will enable the new investor to influence management strategies and decisions via the governance of the company. Funds may pressurise managers to expand or contract the firm, to acquire or divest divisions and subsidiaries, and to pursue greater product market share and / or to maximise revenues. In this sense the influence of investment funds on strategy is direct. There may also be more indirect effects in so far as pressure on 
companies to enhance returns to investors may lead managers to revise their business and corporate strategies.

Second, new owners may affect time horizons. As suggested earlier, HFs tend to have short-term, PE medium-term, and SWFs long-term time horizons. The contrast then is with the time horizons of other owners, such as individuals and families, banks, and institutions such as mutual, pension, and insurance funds. Shorter term horizons, with a high propensity to sell, may lead to higher pay-back demands and a disinclination to invest in longer-term, intangible assets, such as human resources. In practice, this may affect job security and preparedness to invest in training. It may also mean that investors with shorter-time horizons create mechanisms to intensify work and to obtain a quick return on human capital.

Third, new owners may affect performance management in various ways. They may shift the balance between devices based on traditional commitments and ones based on monetary rewards. They may also shift the balance between performance targets based on production and service quality and targets based on financial returns. Any such shift may then, for example, have implications for the use of different sorts of pay systems and pay structures down through the firm.

Fourth, new owners may shift the balance in governance and voice systems within the firm. Thus, new owners may affect the weight of shareholder voice relative to other stakeholders. In terms of employee voice, they may shift the balance between one-to-one direct participation as opposed to representative and collective participation in the firm. Works councils and trade unions may be either favoured or disfavoured.

The extent to which labor is affected by actions by these funds and their investee company is likely to be moderated by national regulatory institutions. The capacity to reduce employment may be affected by employment protection regulation, whilst regulation on employee voice and representation is likely to affect the extent to which labor is informed and 
consulted. Some recent analysis of the impact of PE, for instance, suggests there is an overall negative effect on employment in the US and UK, but not in France, Spain, and Belgium (Boucly, Sraer and Thesmar, 2009; Lutz and Achleitner, 2010). This leads the present authors to propose that national institutional contexts moderate the labor effects of these funds.

Thus, there are various ways in which investment fund ownership may influence firmlevel management behavior and decision-making. In turn, these may affect employment, work, and industrial relations, subject to the moderating effect of national labor regulation. We now provide further details of the extant evidence for each type of fund intervention.

\section{Private Equity}

The case against PE mounted by trades unions and others is that PE transfers value from employees (and taxpayers) to the PE fund, its investors, and its managers. First, initial restructuring of acquired companies may involve asset sales and closure of poorly performing units, leading to lay-offs. Second, it is contended that the financial model operated by PE puts managers under powerful pressures to improve performance via control of free cash flow.

Managers are also typically placed on powerful incentive contracts. These sticks and carrots are said to encourage managers to seek rapid improvements to company performance, often by retrenchment and efficiency improvements, which may in turn have adverse effects on employees. Further, financial engineering may also put employees' pensions at risk because pension assets may be treated as collateral or, where they are a drain on the assets of the firm, sold off to third parties (European Socialist Party, 2008; Clark, 2009a).

Much of the criticism of PE has focused on informational issues. Employees and their representatives have complained that they do not know what is happening during takeovers. Moreover, in Europe, a particular issue with public-to-private transactions is that share-based transfers do not necessarily trigger employment protection and rights to information under 
European Union legislation governing consultation during takeovers (European Socialist Party, 2008).

Counter arguments to these claims are that PE firms have a strong interest in value creation and that PE interventions can lead to employment growth and more secure employment in the longer term. Those cases where PE activity has adverse effects on employees are said to be relatively few, but attract a disproportionate amount of publicity. In any case, these instances tend to be where target firms are poor performers with weak prospects. Thus, it is argued that restructuring would have taken place anyway even without investment fund intervention (European Venture Capital Association, 2008).

The evidence on labor effects relating to these competing claims is mixed and to some extent linked to the methodologies used by researchers. Case study evidence suggests that restructuring following PE takeovers has led to cuts in employment, reductions in wages and benefits, deterioration in working conditions, and reductions in employee voice (Clark, 2009b; Faber, 2006; Kaserer, Achleitner, von Einem and Schiereck, 2007; European Socialist Party, 2008; Service Employees International Union, 2007). There are also some large scale econometric studies which find reductions in employment, or smaller increases in employment than in comparable firms, especially in the immediate aftermath of PE transactions (World Economic Forum, 2008 and 2010; Acharya, Hahn and Kehoe, 2009). Against this, other studies provide evidence of employment growth after PE takeovers (British Venture Capital Association, 2006; Cressy, Munari, and Malipiero, 2007; World Economic Forum, 2010). Some studies differentiate between management buy-outs (involving incumbent managers) and management buy-ins (involving more purely outside PE acquisitions) and find that the latter are more likely to have negative effects on employment (Amess and Wright, 2006).

There is less evidence on the impact on wages and benefits, though again there are divergences in findings. Some case studies highlight cuts in benefits in PE-owned companies 
(Faber, 2006). Thornton (2007) and World Economic Forum, (2010) find that pay grows more slowly in PE-owned firms than in the wider economy. Nevertheless, other research finds wages growth in the period immediately after the acquisition (Wright et al. 2007). Amess and Wright (2007) find that average wages tend to be lower in PE-backed firms than in other firms, especially in buy-ins. However the World Economic Forum (2010) study claims that average wages are higher in PE target firms prior to acquisition, but are reduced to the industry average post-acquisition. Some evidence from the US indicates reductions in employer healthcare provision (Service Employees International Union, 2007).

Whilst some PE-owned firms may reduce employment, they may produce better quality jobs. For the UK, Bacon et al. (2004) and Bruining et al. (2005) present evidence that PEbacked firms use a greater variety of high commitment work practices. After the PE transaction, these firms increase the amount of employee involvement, flexible work practices, and skills training. Similarly, Amess, Brown and Thompson (2007) find that workers in PEowned businesses have more discretion in their work practices than similar workers in non-PE firms. Others, however, have argued that many of these new work practices take the form of 'hard' or manipulative Human Resource Management and impose greater pressures on workers (Thornton, 2007).

In terms of impacts on employee voice and representation, there is also diverse and conflicting evidence. There are instances where PE-acquired companies no longer bargain with trade unions and have reduced employee voice (Evans and Habbard, 2008; Faber, 2006; International Trade Union Congress, 2007). By contrast, in many instances, existing approaches continue more or less unchanged. There are also instances where PE investment funds, as well as PE-backed businesses, choose to work closely with employee representatives (Westcott, 2009; Beeferman, 2009). Indeed, in some cases, trade unions view PE positively because of its potential to rescue failing firms and because it may generate good returns to pension funds 
(Beeferman, 2009). One recent European Union-wide study has suggested that PE firms adapt to national systems of labor representation and that in most instances employee voice institutions tend to be left more or less untouched after buyouts (Bacon et al., 2010).

\section{Hedge Funds}

HFs may also affect employment and labor outcomes in a variety of ways. As already stated, a key factor is that, unlike PE, activist HFs do not usually seek complete control of companies and the average duration of their investment is shorter. Their attention is focused more on changing the behavior of existing managers. In some cases they are concerned with encouraging managers to restructure (e.g. by selling non-core activities), whilst in others their attentions are more focused on directly transferring value to shareholders via share buybacks and increased dividend payments.

The possible effects on labor and employment may be as follows. Where HF activism is focused on encouraging managers to modify business strategies, such as withdrawal or curtailment of certain activities, there may be major effects on work and employment. Where activism is aimed at diverting cash-flow from other stakeholders to shareholders, this may place restrictions on the resources available to reward labor within the firm. Activism focused on securing governance changes, such as board representation and replacements of the chief executive, may lead to changes in company strategy, which may have effects on wages and employment.

Unfortunately, there is very little evidence currently available on the labor effects of HFs. US studies of HF activism have been primarily concerned with examining the objectives of HFs and their effects on company performance (Brav et al, 2008; Klein and Zur, 2009). To date, there have been two European studies on labor effects conducted by the current authors for the European Commission (Wilke, Vitols, Haves, Gospel, and Voss, 2009; Gospel et al., 2010). 
There are also some brief case studies in a report prepared by the Socialist Group in the European Parliament (European Socialist Party, 2008).

\section{Sovereign Wealth Funds}

SWFs have tended to be passive investors, despite their often substantial ownership stakes in investee companies. This suggests that their effects on management behavior may be limited and that there will be little impact on labor and employment. This may be reinforced by the desire of SWFs to stay out of the limelight. However, their investment may affect labor in various ways. On the one hand, it may help maintain employment in struggling firms and create new opportunities for growth. This may also have subsequent beneficial effects on wages and conditions within companies. They may also be prepared to continue supporting pension funds where previous owners may not. On the other hand, in pursuit of good returns, SWF investors may pressure firms to restructure and sell off parts of their operations and concentrate on core activities. It should be remembered also that most SWFs do not come from countries where employee rights and trade union bargaining are strong and this may make them impatient of labor voice. On balance, we expect that the employment consequences of SWF investment will be less strong than PE or HFs, due to the political constraints on their activities and their usually passive interest in the companies in which they invest.

However, to date, there has been only two studies of the labor effects of SWF activity. This was conducted by the current authors for the European Commission, and it was found that there was evidence of transfers of employment and job loss through restructuring. However, there had been little effect on wages and conditions or on employee voice (Wilke et al. 2009; Gospel et al., 2010). 


\section{RESEARCH METHODS}

The research was undertaken drawing on case studies of companies affected by each type of investment fund. The purpose of the case studies was to generate data on labor effects, and thus to contribute to the development and refinement of theory on the links between investment fund activity and aspects of employment, taking into account the potential moderating factors of national labor and employment regulation. The source of these cases was a database, created by the European Commission, of all major PE, HF, and SWF acquisitions and interventions in Europe (further details can be found in Voss, Vitols, Wilke, and Haves, 2009). The cases selected provide examples of the three different types of funds, operating in three of the largest European economies (Wilke et al., 2009). The PE and SWF cases involved 100 per cent acquisitions whereas the HF acquired a minority ( 9 per cent) stake. The size of the PE and HF acquisitions are typical whereas the SWF case is an example of a hitherto less common, but fast growing, level of ownership.

A variety of principles may be adopted to guide case selection (Eisenhardt, 1989). Here the concern was to focus on typical rather than polar cases. This is because the debates on the merits of investment funds, PE especially, have tended to highlight either dramatic restructuring and employment reduction or growth stories in expanding industries. This has tended to inhibit or a full assessment of the effects of these funds and the development of theory on finance-labour linkages. Our cases are typical of the companies selected for intervention by the various funds. All were to some extent under-performing or under-valued companies, but were not in imminent danger of collapse. Restructuring was likely to occur in each case, but was not likely to be a battle for survival. In addition, it was important to select companies which had been affected at a sufficient time in the past so as to distinguish permanent from temporary effects.

The first case deals with a Spanish supermarket company (DinoSol) acquired by a British PE fund (Permira) from a larger listed Dutch company. Retail is the largest single area of PE acquisitions (World Economic Forum, 2008), partly because store groups often have valuable 
property portfolios and partly because cash-flow tends to be positive (i.e. income is received before expenses paid for many product lines). DinoSol was divested from a larger group: acquisition of divisions is the largest single type of PE acquisition activity (World Economic Forum, 2008 ibid.). The second case concerns a German company (Kuka), the target of intervention by a US HF (WyserPratte). Kuka is typical of the substantial number of firms in Germany and elsewhere which have been the subject of HF interventions (Bessler and Holler, 2008; Brav et al, 2008): although profitable at the time, it was believed to be under-valued and had a large free float of shares. The third case is of a British company (P\&O), acquired by a Dubai SWF. This case represents a growing trend amongst SWFs to acquire large stakes in firms and industries of strategic importance to the parent country of the SWF. The cases are summarized in Table 1.

To consider the moderating effects of labor regulation, a further structuring dimension in case study selection was national labor relations context. We therefore selected our company cases from a liberal market economy (the UK), a coordinated market economy (Germany), and one where employment relations takes a hybrid or Latin form (Spain). Two dimensions of industrial relations context are important. One is employment protection, the other is worker voice and representation. The UK is at the bottom of European countries on the Employment Protection Index of the Organisation for Economic Cooperation and Development, whilst Germany and Spain are in the upper half of countries (OECD, 2004). Spain is known for especially well-developed employment protection, deriving from state paternalism from the Franco era. As for worker voice, Germany has well-developed statutory procedures for worker voice, involving representation in works councils and on company boards. Spain too has an extensive system of works councils, though traditionally these bodies have not been involved in workplace restructuring and they lack the codetermination rights possessed by German works councils. In the UK there are various statutory rights to information and consultation, but works councils as such are rare, especially outside of larger firms, and unions have become weak in the private sector. 
Insert Table 1 about here

In each case, semi-structured interviews were carried out through the spring of 2009 using a common questionnaire. Interviews were held with the following: DinoSol (interview with head of Finance, head of Human Relations, two other managers; three union representatives, one union consultant; Permira denied access); Kuka (interview with G. WyserPratte himself and one staff member; interviews with three management representatives; two trade union representatives one of whom was a member of the supervisory board); P\&O (interviews with senior Human Resources representative; five union full-time officers; three union lay representatives; two representatives of specialist maritime consultancy firms; but not the fund, which denied access). In each case, primary documents (company reports, trade union reports, some private materials passed on by representatives) and secondary material (web materials, newspaper, and trade journals) were examined. These materials exist in longer case studies held in a project case study archive and would be available on request (Wilke et al., 2009).

We analysed the effects on three interconnected areas covering a range of labor outcomes (Gospel, 1992). First, employment relations deal with the arrangements governing such aspects of employment as job security, rewards, and benefit systems. Second, work relations are taken to cover the way work is organized and the deployment of workers around technologies and production or service systems, including training. Third, industrial relations are taken to cover the voice aspirations of workers and institutional arrangements which may arise to address them, such as joint consultation, works councils, trade unions, and collective bargaining. 


\section{DinoSol: Spanish supermarket, British private equity fund}

DinoSol is Spain's sixth largest supermarket group, concentrated primarily in the South. Until 2004, the company was owned by the Dutch-listed Ahold Group. However, when the latter got into difficulties and its share price fell in late 2004, Permira - one of the largest British PE houses - acquired the company. To date, DinoSol has been Permira's largest Spanish acquisition. The purchase price was said to be $€ 895 \mathrm{~m}$, which was around half of what Ahold had paid for the company a few years earlier from the Spanish group, Hiplodiplo. At the time of the Permira purchase, it should be noted that not only the parent company, but also DinoSol itself, were in some difficulty. It was widely felt that the company needed to be restructured to compete in an increasingly competitive market. At the time of acquisition, DinoSol employed 11,000 workers.

In line with the PE model, Permira made it clear that the intention was to take DinoSol private, to hold it for five to six years, to restructure it, and then to refloat it at a profit. The business plan has been to dispose of stores where the company is weak, to reinforce investments in geographical areas where it is strong, and to strengthen overall operational activity.

There has been little change in top management personnel in DinoSol and board membership has not been significantly altered. In Spain, Permira has a small group of managers, one of whom is a retailing specialist, hired at the time of the DinoSol acquisition. This individual attends DinoSol board meetings. As suggested to us by management interviewees, Permira lays down broad financial and strategic parameters and then leaves it to DinoSol management to develop these operationally.

According to company management respondents, strategy and operations have developed in the following way since Permira acquired the company. In the first place, DinoSol began a 
sell-and-lease-back programme for some stores, thus freeing up immediate cash for Permira. In early 2006, the company took on additional debt and in early 2007 a dividend of $€ 484 \mathrm{~m}$ was paid to Permira. As will be seen, a small number of stores and offices were closed. Also, some stores were sold in geographical areas where the company was deemed to be weak or where a good opportunity arose. Equally, though, there have been acquisitions of other small companies which were seen to be cheap, had good assets, and could be improved. A few new small stores have been opened, but lack of investment funds has inhibited large-scale acquisitions. As the head of Human Relations put it, 'Permira is tight with money'. Meanwhile, in 2006, Permira itself has made two other smaller Spanish acquisitions in retailing: at the time of writing there has been no attempt to merge these companies.

According to both management and labor respondents, DinoSol has been allowed to make its own decisions in labor relations, without direct involvement by Permira, though the latter has taken a broad overview of strategy. In terms of employment, around 60 stores and offices have been closed or sold, totalling 900 jobs. However, most of these jobs have passed to new owners rather than being lost. Nevertheless, as one union representative said, 'This can be tough on those who have to transfer - very unsettling'. Because of growth and some new acquisitions, total employment now stands at the same as when the acquisition was made. Two other changes in employment conditions moved the company towards a somewhat stronger internal labor market. First, there has been a movement towards making store staff full-time and putting them on open-ended contracts: according to a management interviewee, 'In the longterm, we came to believe this is cost-minimising and good for everyone'. Second, a new pay system has been introduced, emphasising merit, performance, and profitability, at both individual and group level (Wilke et al., 2009).

In terms of work organization, some staff (40) have been retrained and redeployed from office to store and warehouse work. Greater control over absenteeism has also been introduced. 
Simultaneously, it would appear that DinoSol has maintained its training facilities, especially for skilled workers in food preparation departments (meat and fish), and has extended training to other workers.

In terms of industrial relations, there has been one major development. The abovementioned changes have been brought about under an Employment Plan, agreed with the two main unions. For the first time in DinoSol's history, this created a company-wide council, with four management and four employee representatives. In turn, the council has formulated policy on relocation, protection during transfer, and redundancy terms. To monitor this, a joint committee has operated. Note that Spanish law supports the election of works councils at the workplace, but it is not common for company-wide institutions to operate except where collective agreements with unions requires them. Under the Plan, the membership and presence of trade unions has increased and density is now about 12 per cent, high for the retailing sector in Spain. From DinoSol's point of view, the Employment Plan was said by one manager to be 'a way to avoid collateral damage'. Permira is reported not to have been directly involved in this process, but significantly it has not opposed it. One of the two main unions commented: 'we got some sort of company-wide representation for the first time ever'.

In conclusion, the acquisition of DinoSol by Permira was a means whereby the former owner exited from a company which had low profitability and needed restructuring. Permira has acted to refinance the deal and to free up cash within the company. As a result, there has been some small job loss (40), a larger number of transfers $(463$, most but not all with retained pay and conditions), and some changes in terms and working conditions. These changes have been consulted over and would seem to have led to an increase in employee voice in the company. On the whole, Permira appears to have acted in a cooperative way towards the labor force. However, it should be noted that the changes occurred largely during a period of economic upswing. Currently, according to the unions, there is uncertainty about the future and 
a constant fear that the company could be sold. If the sale is to a competitor, such a firm might further restructure the company. However, in the present difficult economic situation in Spain and given the difficulty of finding a good purchaser, Permira may be constrained to hold the company for longer than it had anticipated.

Insert Table 2 about here

\section{KUKA: German engineering company, American hedge fund}

Several big HFs, and a larger number of smaller HFs, have been active in Germany over the last ten years, and they have attracted considerable critical attention. Famously, they have been labelled 'locusts' by politicians and the media (Seifert and Voth, 2006). The case to which we refer here involves a typical German Mittelstand engineering company, KUKA, the American HF Wyser-Pratte, and a number of other HFs.

KUKA is an old-established mechanical and electrical engineering company, with a specialism in automotive equipment and industrial robots. From the 1970s onwards, it was merged with another machine tool, packaging machinery, and control technology group, under the name of IKWA, and, for many years, was a listed company with widely dispersed ownership. The company was profitable, but at a low level, across most of its business activities (Wilke et al., 2009).

Wyser-Pratte was established in 1991 by Guy Wyser-Pratte and is based in New York. The fund has concentrated on investing in under-valued companies and has followed an activist strategy. Over the past decade it has focused on European companies, mainly in Germany, 
where it has attracted considerable public attention. For example, it was involved in the British Vodafone acquisition of Mannesmann, where it was seen as one of the driving forces behind the deal, and it took an active position in the large Rheinmetall group, where it pushed (unsuccessfully) for a major restructuring programme.

In common with other activist HFs, Wyser-Pratte's business model is to search for undervalued companies, to acquire a significant minority stake (usually less than 5 per cent), and to work in combination with other funds. The objectives are to put pressure on management to increase dividends, to initiate share buy-backs, to sell parts of the business, and to change company strategy so as to add value. Sometimes the intervening mechanism is to change the top management team. Usually shares are held until the strategy succeeds and / or a good exit opportunity can be found. Thus, the aim is to increase share price and then sell within a short time period, usually under a year. In our interview with Wyser-Pratte, he reiterated the phrase that he has been credited with vis-à-vis the management of investee companies - 'wake up and smell the napalm'.

Wyser-Pratte first invested in IKWA in 2003 and built up a large 9 per cent holding by 2007. The company was well suited to the pursuit of an activist strategy - it was not particularly profitable, but was under-valued, showed growth potential, and had a large free float of shares. Wyser-Pratte decided that the potential was primarily in industrial robotics where KUKA had been a pioneer. As the strategy developed, Wyser-Pratte was joined by a number of other HFs, with the former acting as a so-called 'alpha wolf' in pressing for change at annual meetings, in company briefings, and in the press.

When Wyser-Pratte first became involved, employment in the IKWA group stood at just over 13,000, across a broad spread of engineering sectors. Over the next five years, the company sold off numerous parts including its large package machinery subsidiary, leading to a reduction in employment by around 7,000 staff. This was under strong pressure from Wyser- 
Pratte and some other investors, including other HFs. This restructuring led to considerable conflict between investors and IKWA's board. In the process, the company was renamed KUKA, and did indeed come to concentrate more on industrial robots and systems engineering, while remaining dependent on the automotive industry. In practice, Wyser-Pratte would have liked the restructuring to have gone further, with even more concentration on robotics, with the aim of making KUKA into the world leader in this sector.

In the labor relations area, IKWA and then KUKA management have made their decisions subject to activist pressure from Wyser-Pratte and other HFs, but with the constraint of employee board-level representation, strong works councils, and trade union membership (as is common in the German metalworking industry) (Wilke et al., 2009).

The main change has been in terms of employment, with a reduction of around 7,000 jobs. However, there have been few lay-offs or job losses, and most of the reduction has come from transfers to new owners. Interestingly, a majority of these new owners were PE funds who bought parts of the business from KUKA. Unfortunately it has not been possible to ascertain what has happened to employment following the sale by KUKA nor what has happened to terms and conditions in the new owning companies. In other words, it is not possible to estimate whether there has been a net decrease or increase in jobs. In interviews, however, KUKA management and unions' views were that there has been no overall job loss. Similarly, both KUKA management and union representatives told us that changes in work and working conditions have been normal for the sector. Moreover, as with all these cases, the counterfactual must be taken into account, namely what might have happened in the absence of HF activism.

In terms of industrial relations, union representatives indicated that worker directors and works councillors have had little direct dealings with Wyser-Pratte. However, decisions about sales and transfers were communicated to employees, works councillors, and trade union 
representatives. Typically for Germany, as members of the company supervisory board, works councillors and union representatives were provided with information. In fact, from interviews it would appear that employee representatives and the trade unions accepted some of the general logic of restructuring and transfer of employees. They also played a part in making arrangements with management for job guarantees and assurances on pay and conditions.

The main outcome of the restructuring following the HF intervention has been that KUKA is now a much smaller company, specialising in two particular sub-sectors, automotive and robotics. HF activity played a significant part in this restructuring and in the speed of divestments. As one manager said, 'This may be a good thing, but it certainly involved a fight and uncertainty for staff'. After initial losses in 2005 and 2006, profits increased in 2007, though this was a good year generally for the metalworking sector in Germany. Subsequently, in the recession from 2008 onwards, profits have fallen. The share price rose markedly during the restructuring period, but then also fell steeply in 2008, as did the price of other automotive stocks. 2009 brought further changes for KUKA, with the German family-owned machinebuilding company, Grenzebacher, acquiring 30 per cent of shares and announcing a close cooperation between the two companies and a change in KUKA's management. However, Wyser-Pratte is still invested in KUKA as a good exit opportunity has not been found.

\section{P\&O: UK ports and logistics company, Dubai sovereign wealth fund}

The UK has been the most significant country in Europe in terms of investment funds. It has been the main country for PE and HFs (both as headquarters for funds and also as a location for their investment). It has also been a major investment location for SWFs. The SWF model has taken various forms in the UK, ranging from relatively small holdings, to larger holdings on a longer term basis, and to some acquisitions of a whole company. The case of Dubai World / Dubai Ports World and P\&O falls into the latter category. 
Dubai World is a Dubai government-owned holding company, under the control of the Dubai ruling family. Under the Dubai World umbrella are the following: Dubai Ports World, the investment company Istithmar, the property developer Nakheel, and a number of other companies and funds. Dubai Ports World was created, under Dubai World, to develop Dubai as a major transhipment centre and to constitute a global logistics company. In addition, there is the Investment Corporation of Dubai, another family / government investment vehicle. The financial basis of the fund are past oil revenues (now largely depleted), earnings from other sources, and borrowings from neighbouring Emirate states, especially oil-rich Abu Dhabi, and from world money markets.

For its part, $\mathrm{P} \& \mathrm{O}$ was an old-established UK shipping and ports operating company, with significant world-wide interests. Its shares were widely dispersed and traded on a number of stock exchanges. Under a number of chief executives, it had diversified into ferries, real estate, construction, and other areas, and by the early 1990s was something of a conglomerate.

However, in the late 1990s, under pressure from institutional investors, it then divested its construction, property, cruise, and container businesses. The company came increasingly to concentrate on logistics and port terminals, but it also retained a substantial UK ferry business. At the time of the acquisition, it had 22,000 employees worldwide.

In 2005, a bidding contest for P\&O developed between Dubai Ports World and the Singapore SWF Temasek. The former was successful, except that P\&O’s North American port operations were taken out of the deal, having been blocked by the US government. Dubai Ports World paid a 70 per cent premium on the initial share price and the deal was valued at around $£ 4$ bn. The acquisition was an all-cash operation, financed with some existing funds, but also with significant new borrowings, especially from other Arab states.

Having acquired $\mathrm{P} \& \mathrm{O}$, the company was de-listed, headquarters were moved to Dubai, and it was clear that key decisions were to be made in Dubai (even though many non-Dubai 
senior managers were retained). Subsequently, in late 2007, Dubai Ports World was listed on the Dubai stock exchange, with eligibility for 20 per cent of the shares but these being restricted to nationals of Gulf states. Dubai Ports World stated to us that 'the organization, though owned by a single shareholder, the state of Dubai, is run entirely on commercial terms' and that the 'the $\mathrm{P} \& \mathrm{O}$ acquisition is not a portfolio, but a strategic investment'. Since then it has acted to integrate operations and develop the company as a major logistics operator.

In the labor area, given the short time period which has elapsed and given a lack of transparency, it is difficult to ascertain what has been the effect of the Dubai Ports World acquisition. As one UK union official stated to us, 'You don't see them or hear them. It's almost as though they are not there'. In practice, the strategy has been to leave labor relations to local management. As another union official stated: 'We deal with the local people, though these are often new; and Dubai Ports World is always there somewhere in the background'

In terms of employment relations, there has been little reduction in staffing, though as the world economic crisis has continued, this may increase. However, this might well have taken place whoever owned the company, and it is also occurring with other maritime companies (Wilke et al. 2009). There was some fear among the UK unions that Dubai Ports World might sell off the ferry part of the company because it does not fit with its core interests and is not particularly profitable. However, to date, the only announcement which has been made is that the UK-Spanish ferry will be closed at the end of November 2010. In another area, Dubai Ports World is going ahead with the development of a major new container port at ThamesGateway. As one union representative said: 'so far jobs have been kept, but there's a new uncertainty with this new owner - they're not as rich as we thought.'

In the UK, the unions have expressed some concern as to whether Dubai Ports World will meet all its pension obligations to industry schemes. There is some confusion in this respect and legal action is pending. Thus, the state of pension arrangements is unclear, but, it must be 
said that deterioration in pension terms had already occurred in the 1990s under P\&O ownership. Meanwhile, employee share ownership plans operated by P\&O were discontinued when Dubai Ports World acquired the company.

In terms of work organization, there is no evidence that there have been changes in working practices, involving the structure of jobs and work intensity. In fact, again, significant changes in these areas had already been brought about by P\&O in the two decades before acquisition. Again according to the union, 'changes had taken place earlier: it was a sort of sorting out, prior to selling off the company'. On the other hand, for its part, Dubai Ports World makes considerable play of its investment in training. As one management spokesman said, 'Our aim it to develop the company and its key human resources'. The unions confirmed that it continues a good tradition in this area, at least in Europe.

In terms of industrial relations, under $\mathrm{P} \& \mathrm{O}$, and now under Dubai Ports World, trade unions are recognised in countries such as the UK, the rest of Europe, Australia, North and South America, and some other jurisdictions. However, negotiations are always at a local level and $\mathrm{P} \& \mathrm{O}$ has refused company-wide bargaining or consultation. At the time of the acquisition, employees and their representatives were informed, but not consulted, by Dubai Ports World. In Europe, there is a European Works Council and the unions have expressed some disquiet that Dubai Ports World might be using this to by-pass collective bargaining. In Dubai, the company does not recognise unions and has not entered into new recognition in any countries where such did not previously exist under P\&O. At a world-wide level, the unions have been unable to establish any dialogue with Dubai Ports World which they would very much like to do. Again, however, to put this in context, the same applied to $\mathrm{P} \& \mathrm{O}$ and also applies to the other major global port operators.

In late 2009, it became apparent that Dubai World had over-extended and over-leveraged itself, that debt obligations could not be fully met on time, and a major crisis ensued. As a 
result, Dubai-owned enterprises have rescheduled certain debts and have drawn on support from its oil-rich neighbor, Abu Dhabi. To date, there is no real evidence of whether or how this has fed through to Dubai Ports World and labor relations, but the case illustrates how new forms of ownership can introduce new uncertainties.

\section{DISCUSSION AND CONCLUSIONS}

These three cases are illustrative of interventions that are made by each type of investment fund. Both the PE and HF acquired under-performing companies and then embarked upon a process of restructuring with a view to enhancing performance. To date, though acquiring the whole company, the SWF has been less interventionist, but it has nevertheless started to restructure some of the operations of its acquisition.

In terms of employment relations, these types of restructuring programmes have attracted criticism from various parties within Europe and beyond on the grounds that they have adverse effects on jobs. These three cases do indeed show that some operations of target companies have been contracted, closed, or divested. At the same time, where activities have been sold, jobs have transferred to new owners. Thus, the net reduction in employment is less than the headline numbers might suggest. Furthermore, the restructuring process at DinoSol also led to further acquisitions and later organic growth which must be set against other earlier losses. We are unable to make a definitive calculation of total job loss or creation, but our cases nevertheless show that such assessments require more information than headline employment reductions.

There are also other factors which need to be considered: in the DinoSol case, for instance, there was a shift to longer term employment and greater employment security for those who continued to be employed within the firm. The manner in which restructuring is carried out is also likely to have a significant impact on employees' subjective experience of the process and transfers are 
undoubtedly unsettling for employees. Individual employee perceptions have been underresearched in this area and potentially have important consequences for actual human resource processes and climate (Boselie and Koewe, 2010).

In terms of work organization, the cases show little change. Working practices have mainly remained unaltered, though there has been an emphasis on securing improvements in efficiency in all cases. However, this does not seem to have been abnormal for the sector. Existing levels of training have been maintained, and even somewhat increased, after the intervention of the investment funds. There is some evidence of greater use of high performance work practices in one of our cases (Dinosol), and this is consistent with some earlier surveybased studies (Bacon et al, 2004: Bruining et al, 2005). One counter-argument to our findings is that time lags are important, and that further and more extensive changes may occur after the point of observation. Whilst we cannot rule this out, other research has shown that restructuring tends to occur relatively early on (Goergen, O’Sullivan, and Wood, 2010 et al. 2010)

In the case of industrial relations, the case studies show little change in the companies acquired by the HF and SWF, but an important change in the Spanish company acquired by the PE firm. An Employment Plan was negotiated with the trade unions which led to a significant enhancement of employee representation. However, consistent with recent survey evidence (Bacon et al, 2010), there was little or no involvement of employees and their representatives at the time of the acquisition. Post-acquisition, statutory and customary rights to information, consultation, and codetermination were respected. Employee representatives have been involved in restructuring decisions to the extent that existing regulation and company traditions allow. In the case of the German HF intervention, the legally binding nature of agreements with the works council and its typical involvement in the sale of operations played a role in influencing employment outcomes. In the three cases, there is no evidence that restructuring 
decisions have been forced through against strong opposition from unions or other employee representatives. Equally, however, it is clear that employee representatives have had little or no contact with the new owners.

Our research also has broader implications. One observation from the case studies is that the level of ownership is less important than the objectives of funds, as far as the magnitude of labor effects are concerned. The largest reduction in employment was found in the case of the HF intervention which had the smallest ownership stake of the three funds. This emanates from the objective of the HF to extract value for shareholders via a change in corporate strategy in a relatively short period of time. By contrast, the other two types of fund, both with a controlling ownership stake, operate on longer time-frames. Labor effects are less dramatic especially in the case of the SWF. One corollary of the short time-frames of HFs, coupled with their strong emphasis on shareholder value, is that they may under-value human capital in the company. By contrast, the time-frames of PE and SWFs tend to be longer, and this may generate a greater appreciation of the role of human capital in corporate success.

HFs have interesting implications for extant corporate governance theory. The dominant view in governance research has been that the propensity for active monitoring, and its probability of success, will correlate with the size of ownership stakes (Becht and Mayer, 2001). Where ownership stakes are small, passive ownership is likely because of the costs of freeriding. Activist HFs belie this, albeit as the exception proving the rule. They are motivated to intervene because they believe the potential benefits of intervention outweigh the costs, and they have an impact that is disproportionate to their ownership stake. Their capacity to exert pressure on incumbent managements might be attributed to passivity amongst other investors, especially where the latter's ownership is fragmented (Judge, Gaur, and Muller-Kahle, 2010). Incumbent managers have to respond to this shareholder activism because of the threat it may 
pose to them and their job tenure. One proposition that might be tested in future research is whether the extent of restructuring, and associated effects on employment and labor, is influenced by the extent of concentration amongst other shareholders.

Our cases are also suggestive for assessments of the moderating role of national labor regulation. Previous research has shown that the activities of these investment funds are concentrated in countries with relatively low employment protection (Bozkaya and Kerr, 2009). The rationale for this is that employment protection will limit the extent of restructuring from which funds attempt to generate or transfer value. However, our German case shows that extensive reductions to employment can be made where there is substantial employment protection. Furthermore, this country has the most extensive regulation in the area of worker voice and representation, with workers having substantial information and decision rights. Whilst it can be dangerous to generalize from one or a small number of cases, our evidence nevertheless suggests that regulatory context does not deter funds from making substantial changes to employment. It also contrasts with the suggestion made recently that, in highly regulated countries, these funds will avoid investing in firms that require major restructuring (Boucly et al, 2009). Our results are consistent with a recent survey which suggests that PE firms adapt to national systems of labor regulation in European countries, and that firms acquired by $\mathrm{PE}$ investors tend to continue with existing employee voice and representation practices (Bacon et al., 2010). Future research might systematically test the proposition that national employment protection and voice regulation has a limited effect on the extent of employment and labor relations restructuring, whilst controlling as far as possible for selection effects.

The fact that national labor regulation does not prevent major reductions in employment within target firms has implications for policy and practice. For those concerned about the employment consequences of interventions by this range of funds, greater regulation of the funds 
themselves (e.g. greater requirements to disclose information) might be more effective than further regulation on employment protection (Bacon et al.2010). It is true that there are some loopholes in labor law which might be closed: for instance, workers' rights to information and consultation are not generally triggered by changes in ownership by share transfer. However, recent legislative activity in Europe has concentrated on regulating the funds themselves rather than enhancing labor law as such. The Alternative Investment Fund Managers Directive, recently passed by the European Parliament and adopted by the European Council of Ministers, requires that PE and HFs managing investments above a certain threshold should disclose more information about structure, strategy, and investors.

A further implication is that there is more ground for cooperation between funds, management, and labor than is often thought (Westcott, 2009). Elements of cooperation were to be found in the first two cases, a bargained compromise with unions in the Spanish case and a consultative enterprise with a works council and local management in the German case, albeit with a trade union in the background. These would suggest that employee voice, if mobilised, can play an important and potentially constructive role in fund interventions.

Overall, our case study evidence adds to a more balanced view of new investment funds which is coming to the fore in the literature. These funds are neither necessarily 'angels nor demons' in terms of their impacts on labor in their investee firms (Lutz and Achleitner, 2010). Though there are limits to generalization from a small number of case studies, the evidence from our cases helps understand the complexity of labor impacts in their wider corporate context. The article adds to the emergent literature by highlighting the role and limitations of national regulation as a moderating factor on the impacts of various types of investment fund. It is also to be hoped that our results will assist in further developing theory and empirical research on this topic. 
TABLE 1.

Case Study Companies and Investment Funds

\begin{tabular}{|l|l|l|l|l|l|l|l|l|}
\hline Name & $\begin{array}{l}\text { Country } \\
\text { of origin }\end{array}$ & Sector & $\begin{array}{l}\text { Initial } \\
\text { Employ } \\
\text { ment }\end{array}$ & $\begin{array}{l}\text { Investor } \\
\text { type }\end{array}$ & $\begin{array}{l}\text { Name and } \\
\text { country of } \\
\text { origin of } \\
\text { fund }\end{array}$ & Shares & $\begin{array}{l}\text { Transaction } \\
\text { values }\end{array}$ & Sold by \\
\hline DinoSol & Spain & Retail & 11,000 & PE & $\begin{array}{l}\text { Permira, } \\
\text { UK }\end{array}$ & $100 \%$ & $€ 895 \mathrm{~m}$ & $\begin{array}{l}\text { Ahold } \\
\text { Group }\end{array}$ \\
\hline KUKA & Germany & Engineering & 13,000 & HF & $\begin{array}{l}\text { Wyser- } \\
\text { Pratte } \\
\text { US }\end{array}$ & $9 \%$ & $€ 11 \mathrm{~m}$ & $\begin{array}{l}\text { Stock } \\
\text { market }\end{array}$ \\
\hline P\&O & UK & Logistics & 22,000 & SWF & $\begin{array}{l}\text { Dubai } \\
\text { Ports } \\
\text { World } \\
\text { Dubai }\end{array}$ & $\begin{array}{l}100 \% \\
\text { and } \\
\text { then } \\
80 \%\end{array}$ & $\$ 4 \mathrm{bn}$ & P\&O \\
\hline
\end{tabular}

Notes: employment figures are for 2004/5 
TABLE 2.

Labor Outcomes 2005 - 2009

\begin{tabular}{|c|c|c|c|c|c|c|}
\hline $\begin{array}{l}\text { Compan } \\
\mathbf{y}\end{array}$ & $\begin{array}{l}\text { Workforce } \\
\text { consulted in } \\
\text { acquisition }\end{array}$ & $\begin{array}{l}\text { Net headcount } \\
\text { employment } \\
\text { change }\end{array}$ & $\begin{array}{l}\text { Disposal } \\
\text { of assets } \\
\text { and } \\
\text { employme } \\
\text { nt } \\
\text { transfer }\end{array}$ & $\begin{array}{l}\text { Significant } \\
\text { change in } \\
\text { pay / } \\
\text { benefits }\end{array}$ & $\begin{array}{l}\text { Significant change } \\
\text { in work } \\
\text { organization }\end{array}$ & $\begin{array}{l}\text { Change in } \\
\text { employee } \\
\text { 'voice' and } \\
\text { representat- } \\
\text { ion }\end{array}$ \\
\hline DinoSol & No & $\begin{array}{l}\text { Medium } \\
\text { reduction } \\
\text { initially, but } \\
\text { mainly transfers. } \\
\text { Then return to } \\
\text { initial headcount } \\
\text { because of } \\
\text { acquisitions and } \\
\text { growth }\end{array}$ & Medium & Small & $\begin{array}{l}\text { Small; increase in } \\
\text { training }\end{array}$ & $\begin{array}{l}\text { Yes, } \\
\text { increase }\end{array}$ \\
\hline KUKA & No & $\begin{array}{l}\text { Large reduction } \\
\text { (around } 7,000) \text {, } \\
\text { due to transfers. }\end{array}$ & Large & No & No & No \\
\hline $\mathrm{P \& O}$ & No & Small reduction & No & $\begin{array}{l}\text { No change } \\
\text { to core } \\
\text { benefits but } \\
\text { employee } \\
\text { share plans } \\
\text { discontinued }\end{array}$ & No & $\begin{array}{l}\text { Small } \\
\text { decrease }\end{array}$ \\
\hline
\end{tabular}




\section{BIBLIOGRAPHY}

Acharya, V., Hahn, M. and Kehoe, C. 2009. Corporate governance and value creation: evidence from private equity. Available at SSRN: http://ssrn.com/abstract=1324016

Aguilera, R. 2005. Corporate governance and employment relations: Spain the context of Western Europe in: Howard Gospel and Andrew Pendleton (Eds.), Corporate Governance and Labor Management: an International Comparison. Oxford: Oxford University Press.

Amess, K. and Wright, M. 2007. The wage and employment effects of leveraged buyouts in the U.K., International Journal of Economics and Business, 142: 179-195.

Amess, K., Brown, S. and Thompson, S. 2007. Management buyouts, supervision and employee discretion, Scottish Journal of Political Economy, 544: 447-474.

Bacon, N., Wright, M. and Demina, N. 2004. Management buyouts and human resource management, British Journal of Industrial Relations, 422: 325-347.

Bacon, N., Wright, M., Scholes, L., and Meuleman, M. 2010. Assessing the impact of private equity on industrial relations in Europe, Human Relations, 63 9: 1343-1370.

Becht, M. and Mayer, C. 2001. Introduction, in: Fabrizio Barca and Marco Becht (Eds.), The control of corporate Europe. Oxford: Oxford University Press.

Beeferman, L. 2009. Private equity and American labor: pragmatic responses mirroring labors strengths and weaknesses Journal of Industrial Relations, 51: 543-556.

Bessler, W. and Holler, J. 2008. Capital markets and corporate control: empirical evidence form hedge fund activism in Germany. Working Paper, Center for Finance and Banking, Justus-Liebig University, Giessen.

Boselie, P. and Koene, B. 2010. Private equity and HRM: "barbarians at the gate!" HR's wakeup call, Human Relations, forthcoming in 2010.

Bortolotti, B., Fotak, V., Megginson, W. and Miracky, W.2008. Sovereign wealth fund investment patterns and performance, EFA 2009 Bergen Meetings Paper. Available at SSRN: http://ssrn.com/abstract=1108585

Boucly, Q., Sraer, D. and Thesmar, D. 2009. Leveraged buy-outs - evidence from French deals, Global Economic Impact of Private Equity Report 2009. Geneva: World Economic Forum.

Bozkaya, A. and Kerr, W. 2009. Labor regulations and European private equity, Working Paper 08-043, Harvard Business School, Cambridge, MA.

Brav, A., Jiang, W., Partnoy, F. and Thomas, R. 2008. Hedge fund activism, corporate governance, and firm performance. Journal of Finance, 63 (4): 1729-1775.

Briggs, T. 2007. Corporate governance and the new hedge fund activism: an empirical analysis. Journal of Corporation Law, 32 (4): 
British Venture Capital Association 2006. The economic impact of private equity in the UK. London: BVCA.

Bruining, H., Boselie, P., Wright, M. and Bacon, N. 2005. The impact of business ownership change on employee relations: buyouts in the UK and the Netherlands, International Journal of Human Resource Management 16: 345-365.

Clark, I. 2009a. The private equity business model and associated strategies for HRM: evidence and implications International Journal of Human Resource Management, 20 (10): 20302048.

Clark, I. 2009b. Private equity in the UK: job regulation and trade unions Journal of Industrial Relations, 51: 489-500.

Cressy, R., Munari, F. and Malipiero, A. 2007. Creative destruction: evidence that buyouts cut jobs to raise returns. Working Paper, University of Birmingham, Birmingham.

Deutsche Bank Research 2009. Staatsfonds und interventionspolitik-der aktuelle stand , db research paper, Deutsche Bank, Frankfurt.

Eisenhardt, K. 1989. Building theories from case study research. Academy of Management Review, 14 (4): 532-550.

European Venture Capital Association 2008. The impact of private equity-backed buyouts on employee relations, Zaventum: EVCA.

European Venture Capital Associaiton 2005. Employment contribution of private equity and venture capital in Europe. Zaventem: EVCA

European Socialist Party 2008. Hedge funds and private equity-a critical analysis, Report of the PSE-Group in the European Parliament, Brussels.

Evans, J. and Habbard, P. 2008. From shareholder value to private equity - the changing face of financialisation of the economy. Transfer, 14 (1): 63-76.

Faber, O 2006. Financzinvestoren in Deutschland - portraits und investitionbeispiele unter besonderer berucksichtigung der auswirkungen auf die beschaftigung, Arbeispapeir 123, Hans-Bockler-Stiftung, Frankfurt.

Folkman, P., Froud, J., Williams, K. and Johal, S. 2009. Private equity: levered on capital or labor Journal of Industrial Relations, 51: 517-527.

Goergen, M., O'Sullivan, N., and Wood, G. 2010. Private equity takeovers and employment in the UK: some empirical evidence. Working Paper, Sheffield University Management School, Sheffield.

Gospel, H. 1992. Markets, firms, and the management of labor in modern Britain, Cambridge University Press, Cambridge.

Gospel, H., Haves, J., Pendleton, A., Vitols, S., and Wilke, P. 2010. The Impact of investment funds on restructuring practices and employment levels, Dublin, European Foundation. 
Gilligan, J. and Wright, M. 2010. Private equity demystified. London: ICAEW.

International Trades Union Congress 2007. Where the house always wins: private equity, hedge funds and the new casino capitalism. Brussels: International Trade Union Confederation.

Judge, W., Gaur, A., and Muller-Kahle, M. 2010. Antecedents of shareholder activism in target firms: evidence from a multi-country study, Corporate Governance: an International Review, 18 (4): 258-273.

Kaserer, C., Achleitner, A-K., von Einem, C and Schiereck, D. 2007. Private equity in Deutschland: rahmenbedingungen, ökonomische bedeutung und handlungsempfehlungen. Norderstedt: Books on Demand.

Klein, A. and Zur, E. 2009. Entrepreneurial shareholder activism: hedge funds and other private investors, Journal of Finance, 64 (1): 187-229

Lutz, E and Achleitner, A.K. 2010. Angels or demons? Evidence on the impact of PE firms on employment, Working Paper, CEFS, Technical University of Munich, Munich.

Organisation for Economic Cooperation and Development 2004. Employment Outlook. Paris: OECD.

Organisation for Economic Cooperation and Development 2007. The implications of alternative investment vehicles for corporate governance: a synthesis of research about private equity firms and activist hedge funds. Paris: OECD, Steering Group on Corporate Governance.

Seifert, W. and Voth, H-J. 2006. Invasion der heuschreken, Berlin, Econ Verlag.

Service Employees International Union 2007. Behind the buy-outs: inside the world of private equity. New York: SEIU.

Sethi, A. 2008. Sovereign wealth funds, private equity funds, and financial markets. Journal of Private Equity, 11 (4): 12-27.

Thornton, P. 2007. Inside the dark box: shedding light on private equity. London: the Work Foundation.

Trades Union Congress 2007. Private equity-a TUC perspective. Trades Union Congress evidence to the Treasury Committee inquiry, London: TUC.

Vitols, S. 2008. Private equity: financial engineering or solution to market failure, in E. Hein, T. Niechoj, P. Spahn, A. Truger eds., Finance-led capitalism? Macroeconomic effects of changes in the financial sector, Marburg: Metropolis-Verlag.

Voss, E., Vitols, S., Wilke, P., and Haves, J. 2009. Data collection study on the impact of private equity, hedge and sovereign funds on industrial change in Europe, Report prepared for the European Economic and Social Committee, Wilke, Maack und Partner, Hamburg.

Watt, A. 2008. The impact of private equity on European companies and workers: key issues and a review of the evidence. Industrial Relations Journal, 39 (6): 548-568. 
World Economic Forum 2008. Globalization of alternative investments. The global economic impact of private equity report 2008. Working Papers Volume 1, Geneva: World Economic Forum.

World Economic Forum 2009. Globalization of alternative investments. The global economic impact of private equity report 2009, Working Papers Volume 2, Geneva: World Economic Forum.

World Economic Forum 2010. Globalization of alternative investments. The global economic impact of private equity report 2010. Working Papers Volume 3, Geneva: World Economic Forum.

Westcott, M. 2009. Private equity in Australia. Journal of Industrial Relations, 51: 529-542.

Wilke, P., Vitols, S., Haves, J., Gospel, H. and Voss, E. 2009. The impacts of private equity investors, hedge funds and sovereign wealth funds on industrial restructuring in Europe as illustrated by case studies. Report to European Commission: Employment, Social Affairs and Equal Opportunities, Wilke, Maack and Partners, Hamburg. 